\title{
Papaya ringspot virus Populations From East Timorese and Northern Australian Cucurbit Crops: Biological and Molecular Properties, and Absence of Genetic Connectivity
}

Solomon Maina, School of Agriculture and Environment and Institute of Agriculture, Faculty of Science, The University of Western Australia, Crawley, WA 6009, Australia; and Cooperative Research Centre for Plant Biosecurity, Canberra, ACT 2617, Australia; Brenda A. Coutts, Department of Agriculture and Food Western Australia, South Perth, WA 6151, Australia; Owain R. Edwards, CSIRO Land and Water, Floreat Park, WA 6014, Australia; and Cooperative Research Centre for Plant Biosecurity, Canberra, ACT 2617, Australia; Luis de Almeida, Seeds of Life Project, Ministry Agriculture and Fisheries, Dili, East Timor; Abel Ximenes, DNQB-Plant Quarantine International Airport Nicolau Lobato Comoro, Dili, East Timor; and Roger A. C. Jones, Department of Agriculture and Food Western Australia, South Perth, WA 6151, Australia; Institute of Agriculture, Faculty of Science, The University of Western Australia, Crawley, WA 6009, Australia; and Cooperative Research Centre for Plant Biosecurity, Canberra, ACT 2617, Australia

\begin{abstract}
To examine possible genetic connectivity between crop viruses found in Southeast Asia and Australia, Papaya ringspot virus biotype W (PRSV-W) isolates from cucurbits growing in East Timor and northern Australia were studied. East Timorese samples from cucumber (Cucumis sativus) or pumpkin (Cucurbita moschata and C. maxima) were sent to Australia on FTA cards. These samples and others of pumpkin, rockmelon, honeydew melon (Cucumis melo), or watermelon (Citrullus lanatus) growing in one location each in northwest, north, or northeast Australia were subjected to high throughput sequencing (HTS). When the 17 complete PRSV genomic sequences obtained by HTS were compared with 32 others from GenBank, the five from East Timor were in a different major phylogroup from the 12 Australian sequences. Moreover, the East Timorese and Australian sequences each formed their own minor phylogroups named VI and I, respectively. A Taiwanese sequence was closest to the East Timorese $(89.6 \% \mathrm{nt}$ dentity), and Mexican and Brazilian sequences were the closest to the

Australian (92.3\% nt identity). When coat protein gene (CP) sequences from the 17 new genomic sequences were compared with 126 others from GenBank, three Australian isolates sequenced more than 20 years ago grouped with the new Australian sequences, while the closest sequence to the East Timorese was from Thailand (93.1\% nt identity). Recombination analysis revealed 13 recombination events among the 49 complete genomes. Two isolates from East Timor (TM50, TM32) and eight from GenBank were recombinants, but all 12 Australian isolates were nonrecombinants. No evidence of genome connectivity between Australian and Southeast Asian PRSV populations was obtained. The strand-specific RNA library approach used optimized data collection for virus genome assembly. When an Australian PRSV isolate was inoculated to plants of zucchini (Cucurbita pepo), watermelon, rockmelon, and honeydew melon, they all developed systemic foliage symptoms characteristic of PRSV-W, but symptom severity varied among melon cultivars.
\end{abstract}

Papaya ringspot virus (PRSV; family Potyviridae; genus Potyvirus) causes damaging diseases of papaya (Carica papaya) and cucurbit crops in tropical and subtropical regions worldwide. It is transmitted nonpersistently by different aphid species (Purcifull et al. 1984), and a low rate of seed transmission is reported (Bayot et al. 1990). It has flexuous filamentous particles 760 to $800 \mathrm{~nm}$ long (Purcifull et al. 1984). Biologically, PRSV strains belong to two biotypes. PRSV-W infects watermelon and other cucurbits, but not papaya. PRSV-P infects papaya and cucurbits (Purcifull and Hiebert 1979; Purcifull et al. 1984). Cucurbitaceous weeds act as natural reservoirs for spread of both biotypes to crops (Chin et al. 2007; Zitter et al. 1996). In their respective crop hosts, both PRSV-P and PRSV-W isolates cause leaf and fruit symptoms of mottle, ringspots and deformation, and overall plant stunting. Both seriously diminish fruit yield and marketability (Purcifull et al. 1984; Zitter et al. 1996). PRSV is thought to have

Corresponding author: Roger A. C. Jones;

E-mail: roger.jones@agric.wa.gov.au.

Approval for sampling in East Timor was obtained from the Plant Quarantine Department of the National Directorate of Quarantine and Biosecurity, Ministry of Agriculture and Fisheries, Dili. Permission to import plant material blotted on the FTA cards was obtained from the Australian Federal Department of Agriculture who granted the permit No. IP15004160.

*The $e$-Xtra logo stands for "electronic extra" and indicates that three supplementary tables and two supplementary figures are available online.

Accepted for publication 2 February 2017.

(C) 2017 The American Phytopathological Society originated in the Indian subcontinent and was dispersed from there on several occasions to the rest of the world. PRSV-W probably reflects its ancestral state from which PRSV-P subsequently arose (Bateson et al. 2002; Gibbs et al. 2008; Olarte Castillo et al. 2011).

Within Australia, PRSV-W infects cucurbit crops, causing serious losses in the tropical northwest (Kimberley region of Western Australia [WA]), north (Northern Territory [NT]), and tropical and subtropical northeast (Queensland [QLD] and Northern New South Wales [NSW]). In WA, it infects cucurbit crops growing at Broome and Kununurra in the West and East Kimberley regions, respectively, and in the NT crops growing at Darwin and Katherine. In the northeast, its distribution extends from Cairns in north QLD southward along the pacific coastline to Grafton in northern NSW (BüchenOsmond et al. 1988; Coutts and Jones 2005; Greber 1969; Herrington 1987; Jones 1996). In Australia, the principal cucurbit crops in which PRSV-W causes disease are rockmelon and honeydew melon (Cucumis melo), watermelon (Citrullus lanatus), Jarrahdale pumpkin (Cucurbita maxima), butternut and Kent pumpkin (Cucurbita moschata), zucchini (Cucurbita pepo), and cucumber (Cucumis sativus) (Büchen-Osmond et al. 1988; Coutts and Jones 2005; Coutts et al. 2011a; Greber 1969). PRSV-P infects papaya crops growing in QLD and the NT (Bateson and Dale 1992; Bateson et al. 1994; Thomas and Dodman 1993). In countries immediately north of Australia, PRSV occurs in Indonesia and Papua New Guinea (PNG), but not as yet in East Timor (CABI/ EPPO 2013; Davis et al. 2002; Somowiyarjo 1993). In PNG and the Indonesian province of Papua, only PRSV-W was detected (Davis et al. 2002), whereas only PRSV-P was reported from other parts of Indonesia (e.g., Rai et al. 2015). Elsewhere in Southeast Asia, PRSV was reported in Malaysia, The Philippines, Singapore, Thailand, and Vietnam (AVA 2001; Bayot et al. 1990; CABI/EPPO 2013; Opina 1986; Magdalita et al. 1988, 1990; Wahab 1991; Yeh and Gonsalves 1984). 
Agriculture has been practiced in Southeast Asia for more than 8,000 years (e.g., Hutterer 1983). By contrast, it only commenced in Australia following European colonization in 1788, starting as recently as the 1960s in more remote regions. Therefore, Australia still lacks many viruses and virulent virus strains that cause damaging crop diseases in other parts of the world, while other crop viruses only arrived recently. The majority of introductions arise from international trade in plants and plant products and mostly involve importation of vegetative propagules or seeds unknowingly carrying them (Gibbs et al. 2008; Jones 2009). However, from November to April every year, strong northwesterly monsoonal winds blow across the sea from Indonesia and East Timor toward northern Australia bringing clouds and heavy rainfall. Such wind currents could bring viruliferous insect vectors or migrating birds carrying infected seeds in their guts, thereby introducing viruses. Evidence such spread might have already occurred was provided by analysis of the coat protein (CP) nucleotide (nt) sequences of aphidborne Zucchini yellow mosaic virus (ZYMV; family Potyviridae; genus Potyvirus) isolates from around Australia. Isolates from near Kununurra in the northeast Kimberley region of WA were the only ones demonstrating genetic connectivity with isolates from countries to Australia's north, with the Southeast Asian ZYMV strain occurring in cucurbit crops there but nowhere else (Coutts et al. 2011b). Since PRSV resembles ZYMV in being another potyvirus and infects cucurbits transmitted nonpersistently by aphids, it might have arrived in northern Australia similarly.

This paper tests the hypothesis that "plant viral pathogens of economically important crops are arriving in tropical northern Australia by crossing the sea separating it from its northern neighbors (Maina et al. 2016a-f). Two complete PRSV genome nt sequences are available from Thailand, but none from Australia, or its northern neighbors East Timor, Indonesia, and PNG, or elsewhere in Southeast Asia. The only PRSV nt sequences available from Indonesia and Australia are two CP sequences from QLD, and one each from the NT and the Indonesian island of Bali (Bateson et al. 1994; Rai et al. 2015). None are available from East Timor or PNG. Here, we obtain complete genomes from 17 PRSV-W isolates from cucurbit crops growing in East Timor or northern Australia. These genomes provide the basis for studying: (i) whether genetic connectivity exists between these two PRSV-W populations or between them and PRSV genomes from elsewhere ('genetic connectivity' is a biosecurity term used to describe matching nucleic acid sequence identities among samples derived from different countries), and (ii) whether any of them are recombinants. We also determine whether any genetic connectivity exists between $\mathrm{CP}$ gene sequences from the 17 new genomes and the 126 other $\mathrm{CP}$ sequences already available in GenBank, and describe the biological properties of a newly sequenced northwestern Australian PRSV-W isolate.

\section{Materials and Methods}

Isolate collection. In May 2015, 15 leaf samples were collected, each from a different cucumber or pumpkin plant with virus-like symptoms growing in small family-owned farms in the Alieu, Dili, Loes, and Maubisse districts of East Timor (Fig. 1A; Table 1). Sap from each sample was blotted onto FTA Classic Cards (GE Healthcare, U.K.) as described by Ndunguru et al. (2005). The cards were air dried for $10 \mathrm{~min}$ at room temperature before shipment to Australia. In October 2015, leaf samples from 22 plants with virus-like symptoms were collected from pumpkin, rockmelon, honeydew melon, watermelon, and zucchini crops growing in commercial farms and home gardens at Broome in WA (Fig. 1B). When leaf tissue from these 22 samples was tested for PRSV and ZYMV by ELISA, seven were PRSV-positive but ZYMV-negative. In addition, virus-infected leaf material containing five PRSV isolates kept freeze-dried or desiccated over silica gel was obtained from the Western Australian Department of Agriculture and Food (DAFWA) virus isolate collection: B9 was collected in 2004 in Broome, WA, from a watermelon plant with mosaic symptoms (Coutts and Jones 2005); 24NT and 38NT were collected from watermelon with mosaic in 2014 (24NT), or honeydew melon with mosaic and leaf deformation in 2011 (38NT), both from crops growing near Darwin, NT; 4NT was also from NT (details of sample collection lost); and 16AYR was from watermelon with mosaic growing in 2011 at Ayr, QLD (Table 1).
Glasshouse grown plants, virus culture, and inoculations. Seeds were sown and plants grown in plastic pots filled with potting mix in insect-proofed, air conditioned glasshouses maintained at 19 to $21^{\circ} \mathrm{C}$. Plants of zucchini, watermelon, common bean (Phaseolus vulgaris), Nicotiana benthamiana, Chenopodium amaranticolor, and C. quinoa were grown in steam-sterilized potting mix. To establish PRSV cultures, leaf sap from isolate $\mathrm{B} 9$, and Broome isolates $43 \mathrm{C}$ and $55 \mathrm{C}$ collected in 2014 from pumpkin and watermelon, respectively, were inoculated to zucchini plants. These cultures were maintained by repeated manual inoculation to zucchini cv. Black Jack plants. ZYMV isolate $13 \mathrm{Br}$ was also maintained in zucchini plants. To inoculate plants, leaves from the infected cultures were ground in extraction buffer containing $3 \mathrm{~g} \mathrm{liter}^{-1}$ of monosodium phosphate $\left(\mathrm{NaH}_{2} \mathrm{PO}_{4}\right)$ and $11.5 \mathrm{~g} \mathrm{liter}^{-1}$ of disodium hydrogen phosphate $\left(\mathrm{Na}_{2} \mathrm{HPO}_{4}\right)$, and the infective sap mixed with 'celite' (diatomaceous earth) before being rubbed onto leaves of healthy plants at the two to three true leaf stage.

Enzyme-linked immunosorbent assay (ELISA). Leaf samples were tested for presence of PRSV or ZYMV by double-antibody sandwich ELISA (Clark and Adams 1977) as described previously by Coutts and Jones (2005). Sap from PRSV isolate B9-infected, ZYMV isolate $13 \mathrm{Br}$, and healthy zucchini leaves was included in paired wells to provide positive and negative controls, respectively. Polyclonal antisera to PRSV and ZYMV, neither of which was pathotype-specific, were used, both from DSMZ, Brauschweig, Germany.

Host responses to inoculation. In experiment 1, PRSV isolates 43C and 55C were inoculated to two plants each of watermelon, $N$. benthamiana, and $C$. quinoa. In experiment 2 , infective leaf sap containing isolate $55 \mathrm{C}$ was inoculated to two plants of zucchini, watermelon, common bean, $N$. benthamiana, $C$. amaranticolor, and C. quinoa. One control plant of each species was mock-inoculated with healthy leaf sap. This experiment was repeated. In both experiments, plants were observed for virus symptoms weekly for 6 weeks after inoculation, and samples from inoculated and uninoculated tip leaves tested for PRSV by ELISA 2 or 4 weeks after inoculation, respectively. Uninoculated tip leaves recorded as uninfected were retested after 6 weeks. In experiment 3, infective leaf sap containing isolate $55 \mathrm{C}$ was inoculated to two, four, and six cultivars of watermelon, honeydew melon, and rockmelon, respectively. Two plants of each cultivar were kept as uninoculated controls. All plants were observed for virus symptoms over an 8 week period. Samples from uninoculated tip leaves were tested for PRSV by ELISA 4 weeks after inoculation. Any uninoculated tip leaves recorded as uninfected were retested after 6 weeks.

RNA extraction and RT-PCR. The 15 East Timorese samples previously blotted onto FTA cards were sampled by punching up to 20 discs (approximately $2 \mathrm{~mm}$ diameter) for each sample. Total RNA was extracted from these discs using a ZR Plant RNA MiniPrepTM kit (Zymo Research, Irvine, CA) according to manufacturer's instructions. With the seven PRSV-positive leaf samples from Broome and the dried leaf samples from the five frozen dried or desiccated leaves from plants with virus-like symptoms were sampled and the RNA extracted from them as described above. Crude RNA was treated and quality control done as described previously (Guerret et al. 2017; Maina et al. 2016a-f). RT-PCR was performed with the GoTaq Green master mix (Promega) using generic Potyvirus LegPotyF and LegPotyR primers as described by Webster (2008). Only eight of the 15 East Timorese samples were potyvirus positive.

High throughput sequencing (HTS). Total RNA extracts from the eight potyvirus positive East Timorese samples, the seven PRSV-positive leaf samples from Broome, and the five freezedried or desiccated specimens were used. Libraries were prepared from 0.1 to $1 \mu \mathrm{g}$ of total RNA using a TruSeq Stranded Total RNA Sample Preparation kit with Ribozero Plant (Illumina, San Diego, CA) as described previously (Guerret et al. 2017; Maina et al. 2016a-f).The final size and concentration of each library was verified using Qubit and D1000 ScreenTape (TapeStation 2200, Agilent Technologies). Ten nanomolar library pools were prepared by mixing the libraries to achieve an equal molar concentration of each. To determine the most cost effective coverage, two runs were performed. The first run involved a pool of denatured libraries in a MiSeq using a $2 \times 251$ v2 
kit to generate paired-end reads (Illumina) and a 1\% PhiX spike was included. The second run involved sending ready stranded libraries to Macrogen Inc., South Korea, where the libraries were subjected to HiSeq 2500 using a TruSeq SBS kit v4 (Illumina) with 151 cycles to generate paired-end reads in a multiplex of 24 samples in one lane.

Sequence analysis. After sequencing, RNA-seq reads were first trimmed using CLC Genomics Workbench 6.5 (CLCGW) (CLC bio, Qaigen, Redwood City, CA) with the quality scores limit set to 0.01 , maximum number of ambiguities to two, and removing any reads with less than 60 nt. RNA-seq reads were assembled using the de novo assembly method of CLCGW with settings of automatic word size, automatic bubble size, minimum contig length 1,500, mismatch cost two, insertion cost three, deletion cost three, length fraction 0.5 , and similarity fraction 0.9 . All the contigs were subjected to CLCGW BLAST search tool, and subsequently to PASC sequence comparisons (Altschul et al. 1990; Bao et al. 2014). The contigs were sorted by length and examined individually. All contigs with plant virus matches were used for further analysis. Apart from a cucurbit polerovirus within sample TM50 and ZYMV within sample NT38, PRSV was the only virus found present in the samples. In addition, trimmed reads from CLCGW were imported into Geneious 8.1.7 (Biomatters Ltd, Auckland, New Zealand) (Kearse et al. 2012), before mapping to a reference sequence from GenBank. Mapping was performed with minimum overlap $10 \%$, minimum overlap identity $80 \%$, allow gaps $10 \%$, and fine tuning set to iterate up to 10 times (Kehoe et al. 2014). Consensus sequence integrity was observed and its full length used with the contig of interest from CLCGW in Geneious by alignment with MAFFT (Katoh et al. 2002) to create a final sequence. PRSV coding regions were improved by aligning nt sequences to the aligned deduced amino acid sequences using MUSCLE available in Geneious. Open reading frames (ORFs) were predicted and annotations made using Geneious. Finalized sequences were designated as complete coding sequences based on

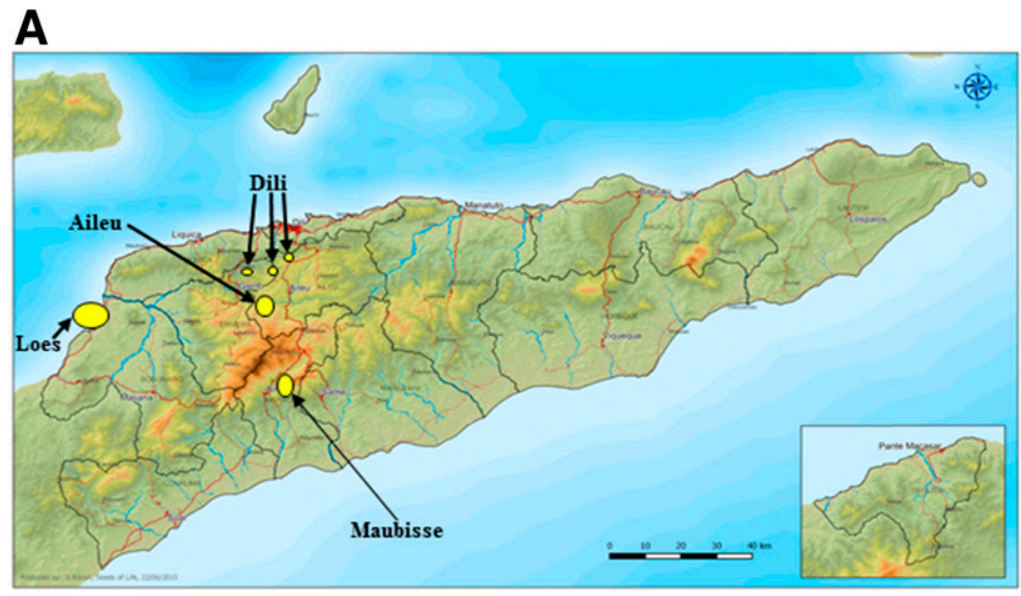

B

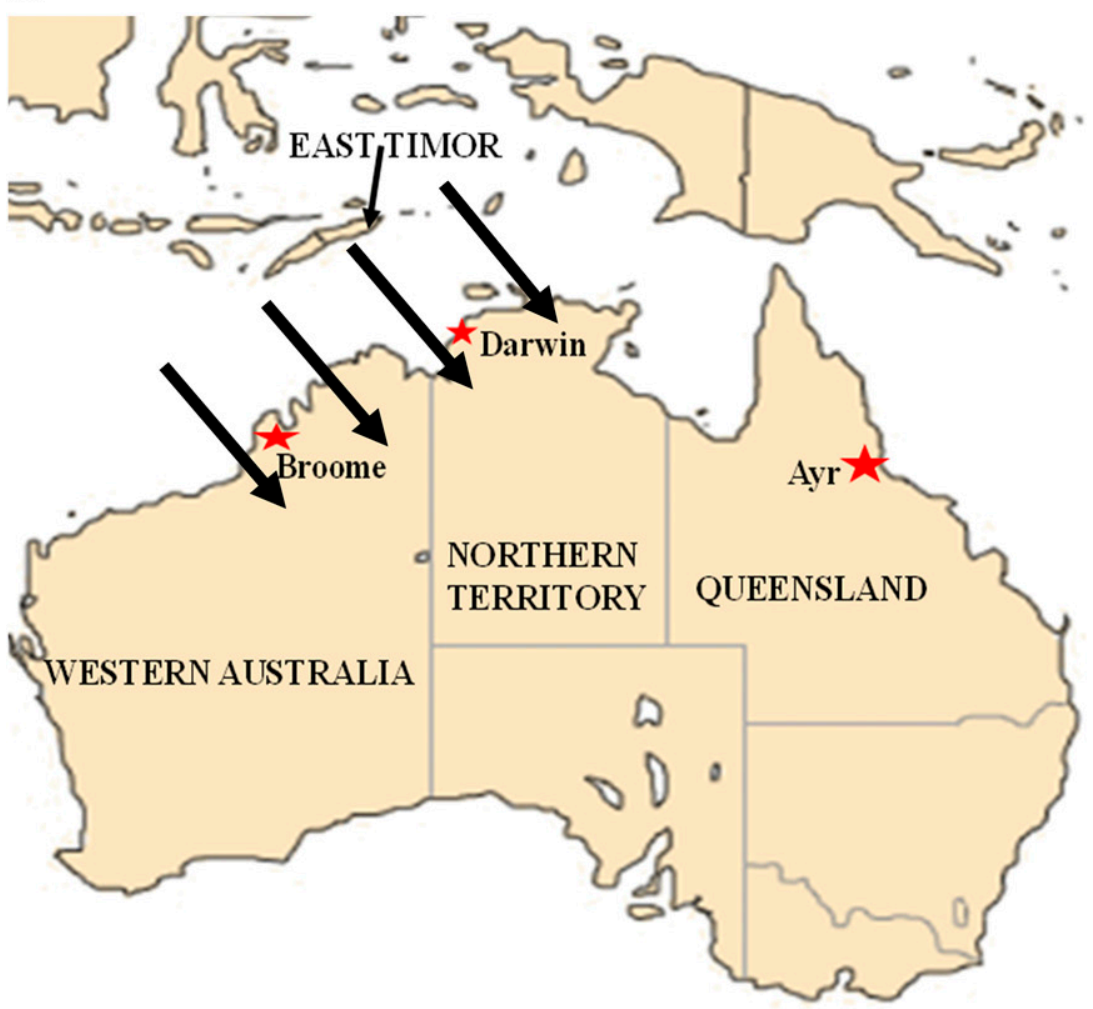

Fig. 1. Maps showing locations in East Timor and northern Australia where leaf samples infected with Papaya ringspot virus (PRSV) were collected from cucurbit crops. A, Sampling locations in East Timor. B, Sampling locations in northern Australia and the position of East Timor in relation to them. Arrows show prevailing monsoonal wind direction in from November to April every year. 
comparison with the reference sequences used in the mapping process, or nearly complete if some of the $5^{\prime}$ or $3^{\prime}$ UTR was missing but the complete polyprotein coding regions were intact. Nt percentage differences were calculated for the complete genomes using the pairwise comparison function in Geneious with the number of differences model. Final sequences were deposited in GenBank under the accession numbers KX655860 to KX655874 and KX998707 to KX998708.

Phylogenetics and nucleotide identities. Using Clustal $\mathrm{W}$ in MEGA 7.0.14 (Kumar et al. 2016), the coding regions of the 15 new non-recombinant PRSV sequences were aligned with those of 24 other non-recombinant PRSV genome sequences from other parts of the world retrieved from GenBank. An additional alignment also included the recombinant genome sequences, making a total of 17 new and 32 other sequences. Supplementary Table S1 provides details of all the complete PRSV sequences from GenBank, including which biotypes they belong to where this is recorded. Further alignment using MAFFT included both nt and amino acid identities (Katoh et al. 2002). Several additional complete PRSV sequences in GenBank were excluded from the analysis due to poor editing, redundancy, or unequal lengths. Phylogenetic analysis compared (i) the coding regions of the new complete genomes from Australia and East Timor, respectively, with other complete PRSV genomes, and (ii) the CP genes from the 17 new complete genomes with the 126 representative $\mathrm{CP}$ nt sequences (excluding highly similar sequences) retrieved from GenBank. The latter included three CP PRSV-P sequences obtained previously from Australia (PRU 14739 from NT, PRU 14744 from Darwin, and GR S89893 from QLD) (Bateson et al. 1994). With the complete genomes, neighbor-joining trees were prepared using the Tamura-Nei model, all with bootstrap values of 1,000 . The codon positions included were first + second + third + noncoding. All ambiguous positions were removed for each sequence pair, and the trees were rooted with two Zucchini tigre mosaic virus (ZTMV) sequences (E11045 KC345608 and Q10 KC345605). Two within-virus species phylogroup classification systems were used. The first was based on the region of the world where each isolate originated (Olarte Castillo et al. 2011). The second uses a neutral nomenclature system involving Latinised numerals that avoids potentially misleading names based on biology or geography (Jones and Kehoe 2016; Nyalugwe et al. 2015). The $\mathrm{CP}$ nt sequences were aligned using Clustal $\mathrm{W}$ in MEGA 7.0.14. A neighbor-joining tree was prepared using the number of differences model. The tree was created with 1,000 replicates and the bootstrap values were percentages with values more than $50 \%$ displayed at the nodes. The tree was rooted with a $\mathrm{CP}$ sequence of Moroccan watermelon mosaic virus accession number AF305545.

Recombination detection. The complete coding sequences of the 17 new genomic nt sequences from northern Australia and East Timor, and 32 others retrieved from GenBank, were assessed for evidence of recombination. The RDP4 package version 4.72 (Martin et al. 2010) was used to detect putative recombination break points between these
49 sequences and excluded any events that carried the warning "this event may not have been caused by recombination". Default parameters were implemented for the seven programs within RDP4: RDP (Martin et al. 2005), GENECONV (Padidam et al. 1999), Bootscan (Martin et al. 2005), MaxChi (Smith 1992), Chimaera (Posada and Crandall 2001), 3Seq (Boni et al. 2007), and SiScan (Gibbs et al. 2000). The analysis also included using a Bonferroni-corrected $P$ value cut off of 0.05 . All sequences for which recombination patterns were detected by four or more programs within RDP4 were considered to contain firm events providing strong evidence of actual recombination, but recombination patterns supported by fewer than four programs were not considered (Ohshima et al. 2002). Using the RDP4 package, the recombination sites identified were examined individually, and a phylogenetic approach confirmed the parental assignments made (Martin et al. 2010, 2015).

\section{Results}

Natural infection. The seven PRSV-infected samples from Broome were from a commercial farm and a garden. They were from watermelon (2), honeydew melon (1), Kent pumpkin (C. moschata) (3), and Halloween pumpkin (C. maxima) (1) (Table 1). The symptoms present in the infected plants were mosaic and leaf deformation in watermelon; mosaic and leaf pallor in honeydew melon; mosaic, chlorotic blotching, reduction in leaf size, and plant stunting in Kent pumpkin (Fig. 2A); and mosaic in Halloween pumpkin.

Host responses to inoculation. In experiment 1, isolate 43C, but not isolate 55C, induced local lesions in inoculated leaves of C. quinoa, and PRSV was only detected in leaf samples from the former (Supplementary Table S2). Both isolates caused vein clearing in young leaves followed by severe mosaic and leaf deformation in watermelon plants, but $N$. benthamiana remained uninfected. In experiment 2 , within-species host responses caused by isolate $55 \mathrm{C}$ infection were identical in both repeats. Zucchini plants developed vein clearing in young leaves followed by severe mosaic, and leaf deformation (Fig. 2B), and their fruits developed yellow mottle, severe malformation, and diminished size (Fig. 2C). Systemic infection in watermelon plants caused initial vein clearing, mosaic, and leaf deformation symptoms (Fig. 2D). No symptoms ever developed in PRSV-inoculated plants of common bean, $C$. amaranticolor, $C$. quinoa, or $N$. benthamiana, and no virus was detected in them. With both experiments, no symptoms ever developed in mock-inoculated control plants, and no PRSV was detected in them. In experiment 3, both cultivars of watermelon inoculated with isolate 55C developed symptoms of initial vein clearing, severe mosaic, leaf deformation and chlorosis, and plant stunting. In contrast, the symptomatic responses of the four honeydew melon cultivars varied from vein clearing alone (cv. HMX 4852) to vein clearing followed by chlorotic blotching, chlorosis, and stunting (cv. Whitehaven). Similar variation in symptom severity occurred with the six rockmelon cultivars. These ranged from vein clearing in young leaves followed by mosaic (cv. Fargo) to vein clearing followed by

Table 1. Details of the 17 Papaya ringspot virus isolates sequenced in this study

\begin{tabular}{llllccc}
\hline Sample & \multicolumn{1}{c}{ Host } & \multicolumn{1}{c}{ Symptoms } & Geographical origina & Year of isolation & Accession No. & Isolate origin/supplier \\
\hline TM3 & Pumpkin & Virus-like & Dili, East Timor & 2015 & KX655865 & This study \\
TM4 & Pumpkin & Virus-like & Dili, East Timor & 2015 & KX655864 & This study \\
TM29 & Watermelon & Virus-like & Dili, East Timor & 2015 & KX655863 & This study \\
TM32 & Pumpkin & Virus-like & Dili, East Timor & 2015 & KX998707 & This study \\
TM50 & Cucumber & Virus-like & Aileu, East Timor & 2015 & KX655874 & This study \\
B9 & Pumpkin & Mosaic & Broome, WA, Australia & 2004 & KX655867 & Coutts and Jones (2005) \\
23C & Watermelon & Mosaic & Broome, WA, Australia & 2015 & KX655861 & This study \\
43C & Kent pumpkin & Mosaic, palor, stunting & Broome, WA, Australia & 2015 & KX655869 & This study \\
45C & Kent, pumpkin & Mosaic, leaf deformation & Broome, WA, Australia & 2015 & KX655870 & This study \\
51C & Kent, pumpkin & Mosaic, leaf deformation & Broome, WA, Australia & 2015 & KX655862 & This study \\
53C & Halloween pumpkin & Leaf deformation & Broome, WA, Australia & 2015 & KX655866 & This study \\
54C & Honeydew melon & Mosaic & Broome, WA, Australia & 2015 & KX998708 & This study \\
55C & Watermelon & Mosaic, leaf deformation & Broome, WA, Australia & 2015 & KX655868 & This study \\
4NT & Unknown & Unknown & NT, Australia & 2014 & KX655860 & Barry Conde \\
24NT & Watermelon & Mosaic & Darwin, NT, Australia & 2014 & KX655871 & Barry Conde \\
38NT & Honeydew melon & Mosaic and leaf distortion & Darwin, NT, Australia & 2011 & KX655872 & Barry Conde \\
16R & Watermelon & Mosaic & Ayr, QLD, Australia & 2011 & KX655873 & Denis Persley \\
\hline
\end{tabular}

${ }^{\mathrm{a}} \mathrm{WA}=$ Western Australia, NT $=$ Northern Territory, $\mathrm{QLD}=$ Queensland . 
severe mosaic, chlorosis, reduction in leaf size, and plant stunting (cv. Triumph) with varying degrees of severity in other cultivars (Fig. 2E and F). PRSV presence was confirmed in inoculated plants of each of cultivar but never in uninoculated control plants.

High throughput sequence data. RNA-seq analysis of the 17 PRSV samples revealed the numbers of raw paired end reads obtained were $1,031,264-21,289,522$, which were reduced to $845,950-20,992,752$ after quality control (removal of low quality and adaptor contaminated reads) (Supplementary Table S3). Following de novo assembly using CLCGW, the numbers of contigs produced were 9-22,622, and the number of reads mapping to the contig of interest were 27,475-5,964,942. The contigs of interest were more than 10,310 nt in length with average coverage of 394-91,899 times. After mapping to a reference genome in Geneious, the lengths of the consensus sequences were more than 10,000 nt, with average coverage of $250-81,650$ times. The numbers of reads that mapped to the reference sequence were $21,031-5,680,415$. Final sequence lengths consisted of the consensus of the contig from CLCGW and the consensus from Geneious, and were 10,223-10,325 nt. All the sequenced samples had a Q30 of more than $98 \%$. The MiSeq platform was used to sequence sample TM3, TM32, and TM50 in one lane multiplexed with 12 other samples. TM3, TM32, and TM50 yielded coverage of more than 1,727, which was sufficient for PRSV genome assembly. This procedure yielded data comparable to that obtained when the other samples were sequenced with HiSeq 2500 in one lane. All samples yielded a complete genomic sequence of PRSV. All the contigs of interest were closely related to PRSV when subjected to BLAST using the PASC (pairwise sequence comparison) tool (Bao et al. 2014), and NCBI Blastn analysis. In total, 17 complete polyprotein coding genomes were obtained from cucumber, pumpkin, and watermelon, five from East Timor (four from Dili and one from Alieu), and 12 from Australia (eight from Broome, three from Darwin, and one from Ayr). Three of the Broome sequences (43C, 51C, 55C) were identical to each other, as were East Timorese sequences TM3 and TM4.

Phylogenetic relationships. Phylogenetic analysis comparing the coding regions of the 15 new non-recombinant genomic PRSV sequences from East Timor and northern Australia with those of the 24 from GenBank revealed two major phylogroups named 'five continents' and 'Asian' using the former geographically based system (Fig. 3). They subdivided into 13 smaller phylogroups (I-XIII). The 'Asian' major phylogroup was made up of nine phylogroups (V-XIII). It contained the three new East Timorese isolate sequences, one sequence from Thailand (also in Southeast Asia), and East Asian sequences from China and Taiwan. The East Timorese sequences formed their own phylogroup (VI). The major phylogroup 'five continents' was made up of four smaller phylogroups (I-IV). It contained all 12 new Australian sequences, and others from Asia, Europe, South America, and North America. Thus, the Southeast Asian sequences from East Timor and Thailand were in an entirely different major phylogroup from the Australian sequences. Moreover, the new northern Australian sequences from Broome, Darwin, and Ayr formed their own individual phylogroup (I). The closest sequences to the East Timorese and Australian phylogroups were WAY010722 from Thailand and Mex-Ur (PO-AY231130) from Mexico, respectively. When the recombinant sequences were included in the phylogentic analysis, the major and minor phylogroups remained the same (Supplementary Fig. S1). When the CP genes of the 17 new PRSV genome sequences from northern Australia and East Timor were compared with those of three other previously reported Australian $\mathrm{CP}$ sequences and $123 \mathrm{CP}$ sequences from the rest of the world, all the 12 new and three earlier Australian sequences grouped together (Supplementary Fig. S2). A single sequence from Poland (PRSVBON - GQ927328) was the only one from another part of the world within this group. The three isolates from East Timor also grouped together, the closest to them being a Thailand sequence (TW-AY010722).

Sequence identities. When the coding regions of the 17 new PRSV genomes were analyzed along with the 32 retrieved from GenBank, the ranges of nt percentage identities within each phylogroup containing more than one isolate were as follows: $\geq 98.4 \%$ (XIII), $\geq 99.6 \%$ (XII), $\geq 97.1 \%$ (XI), $\geq 94 \%$ (IX), $\geq 95.8 \%$ (VII), $\geq 88.3 \%$ (VI), $\geq 85.3 \%$ (IV), $\geq 88.3 \%$ (III), $\geq 88.6 \%$ (II), and $\geq 95.5 \%$ (I). VIII, V, and X were

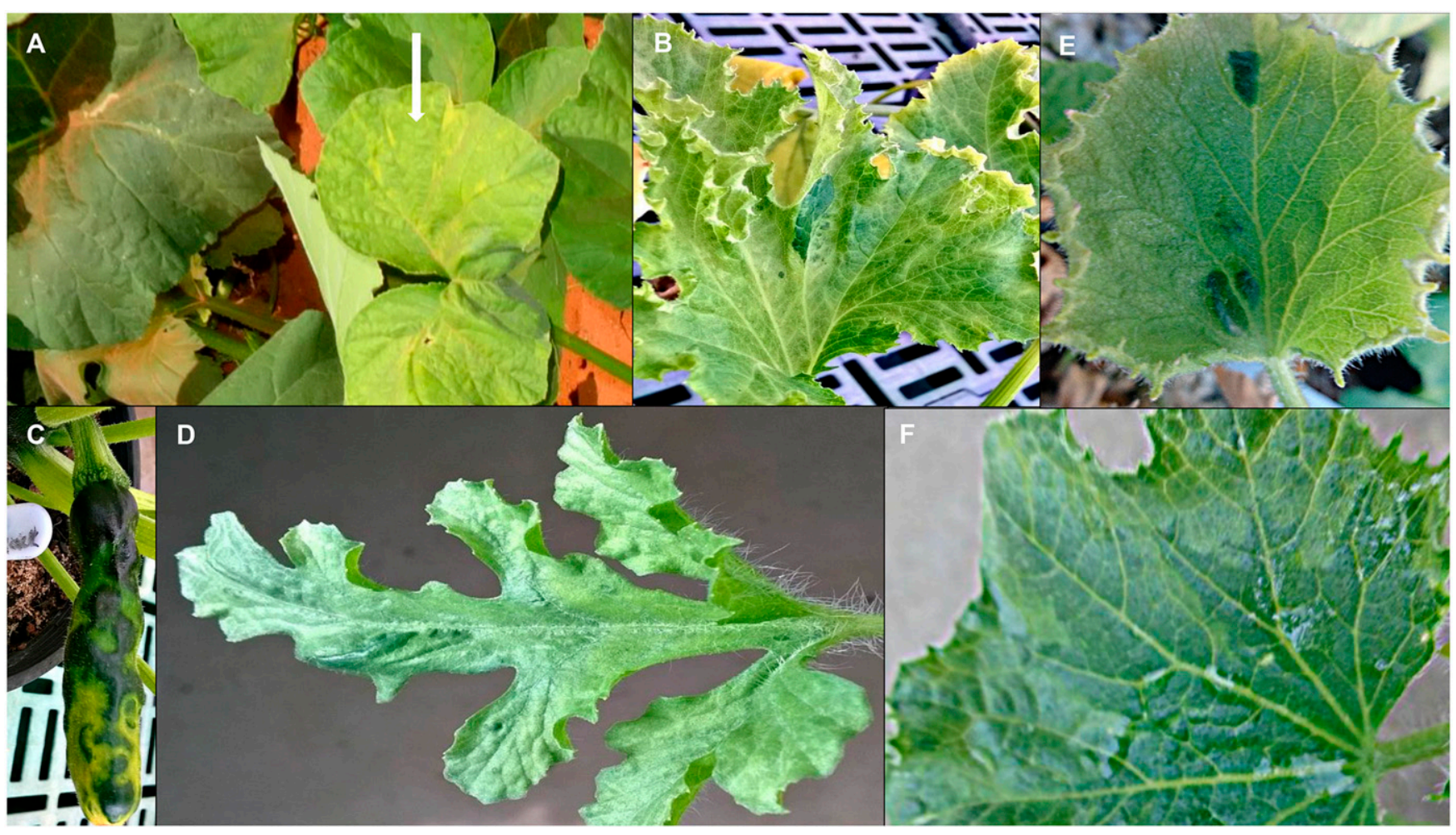

Fig. 2. Symptoms caused by natural infection with Papaya ringspot virus (PRSV) in a pumpkin crop growing at Broome, Western Australia in 2015 (A), or infection induced by mechanical inoculation of cucurbit plants with PRSV isolate 55C (B-F). Leaf of Kent pumpkin (Cucurbita moschata) with yellow mosaic and leaf deformation (white arrow), healthy leaf on left (A); foliage of zucchini (Cucurbita pepo) cv. Black Jack with severe mosaic and leaf deformation (B); fruit of zucchini cv. Black Jack with yellow mottling, severe malformation, and diminished size (C); leaf of watermelon (Citrullus lanatus) cv. Sugar Baby with mosaic (D); leaf of rockmelon (Cucumis melo) cv. Valencia with severe mosaic (E); leaf of rockmelon cv. Sucrose with mosaic $(\mathbf{F})$. 
single isolate phylogroups. With the East Timorese phylogroup (VI), the closest sequence to it was CI (AY027810) from Taiwan in phylogroup X with an $89.6 \%$ nt identity. With the Australian phylogroup (I), the closest sequences to it were E2 (KC345609) from Brazil and Mex-Ur (POAY231130) from Mexico, both within phylogroup II, with $\geq 92.3 \%$ nt identities. When the CP gene sequences from the 17 new PRSV-W genomes from this study were compared with three other previously reported Australian PRSV-P CP sequences from 1984 and the 123 PRSV CP sequences from elsewhere, the East Timorese CPs had a $\geq 93.7 \%$ nt identity. The closest sequence to the East Timorese was iTHW-08 (AY010722) from Thailand, which had 93.1\% nt identity. The 15 Australian CP sequences had an overall $\geq 96.6 \%$ nt identity. The closest sequences to the Australian ones were PRSV-BON (GQ927328) from Poland and Cbmy-1 (KC748229) from Cuba, with nt identities of $97.1 \%$ and $95.1 \%$ respectively, and both fitted within the same grouping.

Recombination patterns. When the complete coding sequences of the 17 new PRSV sequences were compared with the 32 complete coding sequences retrieved from GenBank, the RDP4 package revealed 13 firm recombination events each supported by five or more programs (Fig. 4; Table 2). The Australian isolates were all nonrecombinants. In contrast, TM50 and TM32 from East Timor, and 11 isolates from GenBank contained firm recombination events, nine having one, $\mathrm{W}$ having two, and $\mathrm{KO}-\mathrm{WA}$ with three recombination events. The TM32 and TM50 sequences both contained a single recombination event within the P1 gene near the $5^{\prime}$ end of the genome. The event in TM 50 was detected by seven different programs with a highest $P$-value of $7.732 \times 10^{-11}$, and its major parental sequence was from TM29, while its minor parental sequence was TM3. The event breaking point in TM50 was between nt positions 905 and 1,350. The event in TM32 was detected by five programs with a highest $P$ value of $5.626 \times 10^{-9}$, and its major parental sequence was TM3, while its minor parental sequence was from AY010722 from Thailand. The event breaking point here was between nt positions 568 and 777. Only isolate $\mathrm{W}$ had parents in different major clades. These were major parent JX448371 from the 'Asian' clade and minor parent DQ374152 from the 'five continents' clade.

\section{Discussion}

This research describes the first complete PRSV genomes from cucurbit crops growing in Australia and East Timor. No evidence was found of any genomic connectivity between these two PRSV genome populations that would support the hypothesis that "important plant viral pathogens of economically important crops are arriving in tropical northern Australia by crossing the sea separating it from its northern neighbors." This was because the five genomic sequences from East Timor were in a completely different major phylogroup ('Asian') from the 12 Australian genomic sequences ('five continents'). Also, each formed their own minor phylogroups within these major groupings. Two genomic sequences from the Americas (Brazil and Mexico) in minor phylogroup II were closest to minor phylogroup I containing the Australian genomes, while a genomic sequence from East Asia (Taiwan) in minor phylogroup $\mathrm{X}$ was closest to the minor phylogroup $\mathrm{VI}$ containing the East Timorese genomes. Analysis of CP genes from the 17 new genomes and 453 other CP genes from GenBank found sequences from Cuba and Poland within the Australian grouping, and a sequence from Thailand was closest to the East Timorese group. Recombination analysis found recombinants among the East Timorese

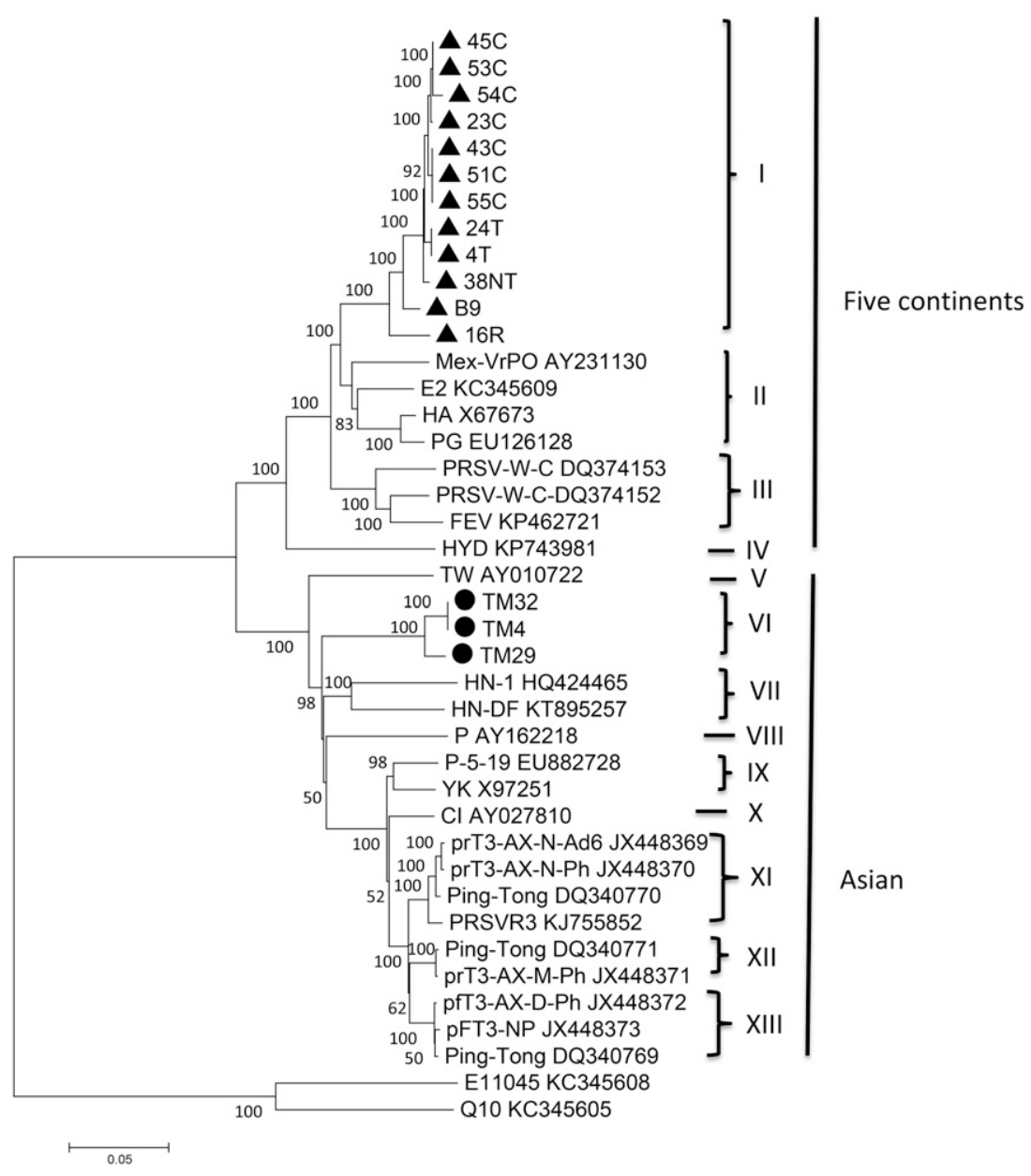

Fig. 3. Neighbor-joining phylogram obtained from alignment of nucleotide (nt) sequences of the 15 non-recombinant isolates of Papaya ringspot virus (PRSV) sequenced in this study with the 24 complete non-recombinant PRSV genomes obtained from GenBank. The tree was created in MEGA 7.0.14 using Clustal W with 1,000 replicates. Bootstrap values are percentages with only values over $50 \%$ shown at the nodes. The tree was rooted with two Zucchini tigre mosaic virus (ZTMV) nt sequences (E11045 KC345608 and Q10 KC345605). The symbols show the 12 and five newly sequenced isolates from Australia $(\mathbf{\Delta})$ and East Timor $(\bullet)$, respectively. 
but not the Australian genomes. Moreover, there was evidence for only a single PRSV introduction, or multiple introductions of very similar isolates, since agriculture commenced in the Australian continent, as the Australian genomes or $\mathrm{CP}$ genes always grouped together. The approach of RNA extraction from FTA cards or infected leaf samples, strand-specific library preparation with plant ribosomal RNA depletion methodology, followed by Illumina sequencing, de novo assembly, and final reference mapping proved effective in obtaining the new genomes. The severity of symptoms caused by an Australian PRSV isolate inoculated to different melon cultivars varied with cultivar.

The addition of 17 PRSV genomes to the database enabled the phylogenetic make up of PRSV to be examined more thoroughly. A major outcome to emerge was the delineation of 13 minor phylogroups named I-XIII within the two major phylogroups recognized previously ('Asian' and 'five continents'). Minor phylogroups V-XIII were within the 'Asian' and I-IV within the 'five continents' phylogroup. The 'Asian' phylogroup consisted of genomes only from Asia, while the 'five continents' phylogroup included Australian, Asian, European, South American, and North American sequences. East Timorese and Australian genomes each formed their own minor phylogroups, VI and I, respectively, each within a different major phylogroup (VI in the 'Asian' and I in the 'five continents'). The closest genomic sequence to the East Timorese was from Taiwan and to the Australian from Brazil and Mexico. Analysis of $\mathrm{CP}$ sequences revealed that the five East Timorese CPs grouped together, and one from Thailand was closest to them. The 12 new Australian CPs and three Australian CPs from 1994 grouped together, but CPs from Europe (Poland) and the Americas (Cuba) also grouped with them. Thus, there was no evidence of genetic connectivity between the East Timorese or Australian phylogroups, and only the East Timorese group had affinities with Southeast Asian PRSV sequences. The presence of all Australian genomes and $\mathrm{CP}$ sequences within the same minor phylogroup suggest only one introduction to Australia, or multiple introductions of very similar isolates, their absence from other phylogroups presumably reflecting (i) its recent introduction well after agriculture commenced 228 years ago, and (ii) stringent Australian quarantine procedures and biosecurity surveillance practices in more recent times. Based on the $\mathrm{CP}$ sequences from Europe and the Americas within the same minor phylogroup, and the previously reported affinity of the three earlier Australian CP sequences from 1994 with ones from the Americas

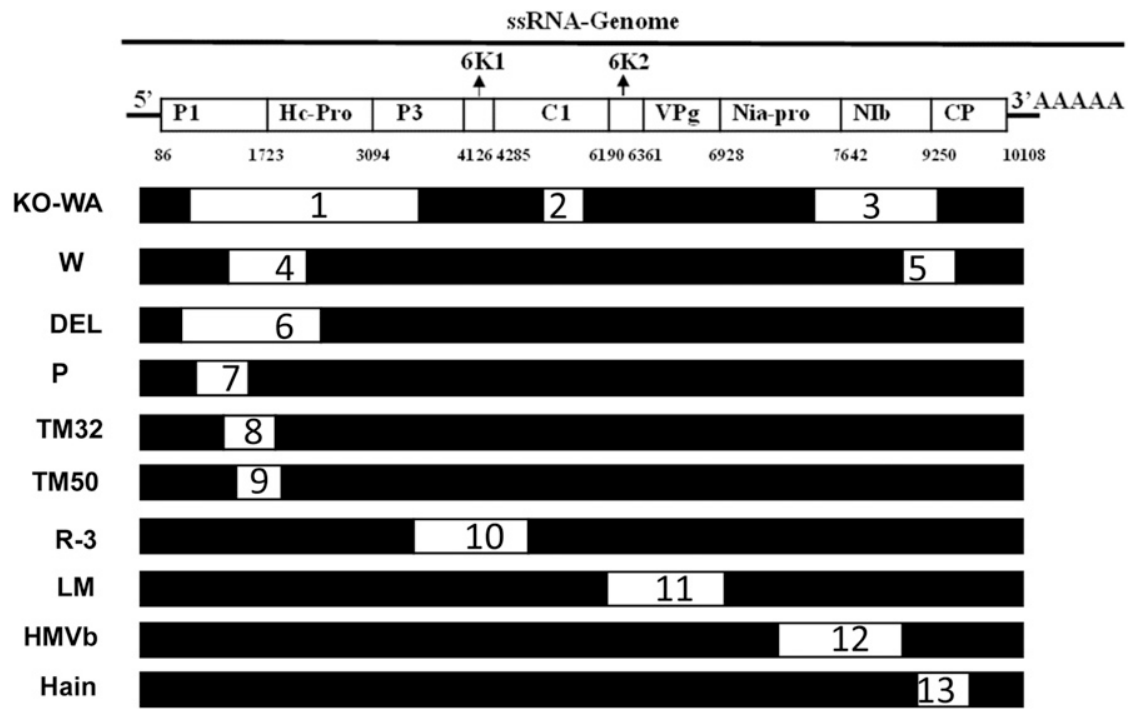

Fig. 4. Recombination events between the coding regions of the 17 isolates of Papaya ringspot virus (PRSV) sequenced in this study and the 32 complete PRSV genomes obtained from GenBank. The locations of genes in the PRSV genome are indicated by the diagram at the top of the figure. White shading corresponds to the recombination events and shows the beginnings and ends of their breakpoints. Black shading designates the non-recombined portions of each genome. Lettering on the right hand side shows the names of each isolate with recombination. Thirteen recombination events were identified by the RDP4 package as shown in Table 2. These isolates were KO-WA (AB369277), W (EU475877), DEL (EF017707), P (EF183499), TM32 (KX998707), TM50 (KX655874), R-3 (KJ755852), LM (KT633943), HNVb (KF791028), and Hain (KF734962).

Table 2. Recombination events between the coding regions of the 17 isolates Papaya ringspot virus (PRSV) sequenced in this study and the 32 complete PRSV genomes obtained from GenBank

\begin{tabular}{|c|c|c|c|c|c|c|c|}
\hline \multirow[b]{2}{*}{ Event } & \multirow[b]{2}{*}{ Isolate } & \multirow[b]{2}{*}{ Accession no. } & \multirow[b]{2}{*}{ Detected break points } & \multicolumn{2}{|c|}{ Parental sequences $^{\mathbf{a}}$} & \multirow[b]{2}{*}{ Detected methods in RDP4 } & \multirow[b]{2}{*}{$P$ value } \\
\hline & & & & Major & Minor & & \\
\hline 1 & KO-WA & AB326977 & $479-3,812$ & DQ340769 ${ }^{b}$ & DQ340771 & 3,S,C,M,G,R,B & $6.439 \times 10^{-16 \mathrm{SI}}$ \\
\hline 2 & KO-WA & AB326977 & $7,007-8,562$ & JX448370 & DQ340771 & 3,S,C,M,G,R,B & $5.563 \times 10^{-03 R}$ \\
\hline 3 & KO-WA & AB326977 & $4,896-5,341$ & AY027810 & KF791028 & 3,C,M,R,B & $9.335 \times 10^{-05 C}$ \\
\hline 4 & $\mathrm{~W}$ & EU475877 & $768-2,464$ & JX448371 & DQ374152 & S,C,M,R,B & $6.248 \times 10^{-07 R}$ \\
\hline 5 & $\mathrm{~W}$ & EU475877 & $8,113-9,034$ & KC345609 & EF017707 & S,C,M,G,R,B & $6.238 \times 10^{-07 M}$ \\
\hline 6 & DEL & EF017707 & $292-2,847$ & AY231130 & EU475877 & $3, \mathrm{~S}, \mathrm{C}, \mathrm{M}, \mathrm{G}, \mathrm{R}, \mathrm{B}$ & $8.137 \times 10^{-07 \mathrm{~B}}$ \\
\hline 7 & $\mathrm{P}$ & EF183499 & $481-973$ & KF734962 & KT633943 & 3,S,C,M,G,R,B & $7.995 \times 10^{-09 \mathrm{Si}}$ \\
\hline 8 & TM32c & KX998707 & $568-777$ & TM3 & AY010722 & 3,C,M,R,B & $5.626 \times 10^{-09 M}$ \\
\hline 9 & TM50 & KX655874 & $905-1,350$ & TM29 & TM3 & 3,S,C,M,G,R,B & $7.732 \times 10^{-11 R}$ \\
\hline 10 & $\mathrm{R}-3$ & KJ755852 & $3,866-4,916$ & DQ340770 & JX448373 & $3, \mathrm{C}, \mathrm{G}, \mathrm{R}, \mathrm{B}$ & $8.814 \times 10^{-09 \mathrm{~B}}$ \\
\hline 11 & LM & KT633943 & $6,130-6,820$ & EF183499 & KT895257 & 3,C,M,G,R,B & $7.805 \times 10^{-04 C}$ \\
\hline 12 & $\mathrm{HMVb}$ & KF791028 & $7,064-8,868$ & KF734962 & KT633943 & $\mathrm{S}, \mathrm{C}, \mathrm{M}, \mathrm{G}, \mathrm{R}, \mathrm{B}$ & $7.461 \times 10^{-05 R}$ \\
\hline 13 & Hain & KF734962 & $9,336-10,056$ & EF183499 & KT633943 & 3,S,C,M,G,R,B & $7.899 \times 10^{-07 \mathrm{SI}}$ \\
\hline
\end{tabular}

a The parental sequences with isolate names instead of accession numbers are all new ones from this study.

${ }^{\mathrm{b}}$ Recombination events identified by the RDP4 package: $3=3 \mathrm{Seq}, \mathrm{B}=$ Bootscsan; $\mathrm{C}=$ Chimera, $\mathrm{G}=$ Gencov; $\mathrm{M}=\mathrm{Maxchi}, \mathrm{S}=$ Siscan.

c TM32 was one of two identical East Timorese sequences. 
(Bateson et al. 2002), its introduction was most likely from the Americas, either directly or indirectly via Europe. Since biotypes PRSV-P and PRSP-W were both present among the Australian sequences in the same CP phylogroup, one could have evolved from the other after its arrival through host switching between papaya and cucurbits. In the future, the availability of more complete genomes of both biotypes and a better understanding of PRSV's global distribution would allow accurate determination of its origins and evolution.

The parental sequences of the two East Timorese recombinants were from East Timor or Thailand, and both East Timorese genomes had recombination events involving their P1 genes. This is consistent with earlier potyvirus studies in which recombination events frequently involved the P1 gene region (Desbiez and Lecoq 2008; Ohshima et al. 2007; Tan et al. 2004). Since recombination provides an important method by which potyviruses evolve and potentially more damaging strains arise (e.g., Gibbs et al. 2008; James et al. 2016; Jones 2009), it is important to sample all cucurbit and papaya growing areas in northern Australia widely, especially from tropical and subtropical QLD, to obtain more genomic PRSV sequences.

Jones and Kehoe (2016) proposed use of Latinized numerals to avoid misleading names and ambiguities arising from within-species plant virus phylogenetic group nomenclature derived from biological properties or geography. Our phylogenetic analyses demonstrate the value of this approach for naming the 13 distinct minor phylogroups in our phylogenetic tree (I-XIII), e.g., in providing the geographically neutral name I for the otherwise predominantly Australian minor phylogroup that also contains CP sequences from Poland and Cuba. Such an approach allows for consideration of the sequences that make up each phylogroup to occur without any preconceived notion based on their names, such as the assumption that they were all isolated from one geographic region. It therefore avoids any serious consequences for virus research, disease management, or international trade that might arise from incorrect assumptions made when current phylogroup names incorrectly identify properties of group members. We have, however, retained geographically based nomenclature for the two major phylogroups for the present, but predict that, due to increasing world trade in plants and plant products, it is only a matter of time before members of the 'Asian' group are detected in other continents. Letters of the alphabet (A for 'Asian' and B for 'five continents') would provide a suitable neutral alteration to major PRSV phylogroup nomenclature once this occurs.

The Ribo-Zero chemistry plant ribosomal RNA (rRNA) depletion approach we used proved very successful in reducing the amount of extracted plant rRNA, as reported previously (Morlan et al. 2012; Nagano et al. 2015). It detected poly-adenylated PRSV in this study and a non-polyadenylated polerovirus (Maina et al. 2016d) efficiently from both high (from leaf material) and low (from FTA cards) integrity RNA. We secured high quality reads with good coverage using MiSeq and HiSeq 2500. However, although MiSeq offers great flexibility (e.g., Loman et al. 2012), our output from it was only 1 to 4.6 million reads while from HiSeq 2500 it was 6.4 to 21.2 million reads. HiSeq 2500 offered the best value for cost, accuracy, and high throughput reads in this study, as reported previously with other systems (Liu et al. 2012; Reuter et al. 2015). Although traditional genome sequencing methodologies (e.g., 454 Roche) have emphasized coverage of more than 30 times, we were able to obtain coverage of $>91,000$ times with some samples, possibly due to high viral titer. This approach was exploited previously in transcriptome sequencing studies with animals and plants where it proved accurate and reproducible (e.g., Bailey et al. 2016; Levin et al. 2010; Stranneheim et al. 2011). Sequence data from strand-specific libraries are more reliable than data from unstranded libraries and can accurately determine expression of antisense RNA (asRNA) and other overlapping genes as well as direction of intronic reads (Sigurgeirsson et al. 2014). We recommend plant virology researchers use strand-specific data to detect RNA viruses because it gives greater confidence in data analysis and is less likely to cause false detections during bioinformatics analyses.

Our study of the responses of melon cultivars to inoculation with an Australian PRSV isolate confirmed that infection with PRSV-W causes foliage symptoms like those reported previously for PRSV in cucurbits in Australia and other countries (Büchen-Osmond et al.
1988; Coutts and Jones 2005; Greber 1969; Purcifull et al. 1984; Zitter et al. 1996). When plants of different melon cultivars became infected, foliage symptom severity and type varied with cultivar.

Although we found no evidence of genetic connectivity between PRSV populations from East Timor and northern Australia, more thorough testing of the hypothesis mentioned in the Introduction would require analysis of PRSV genomes from Indonesia and PNG. It would also require analysis of additional PRSV genomes from QLD and some from northern NSW as these regions were only represented by one genome and QLD is where the countries' cucurbit and papaya industries are most extensive. Moreover, as climate change progresses, increasingly severe extreme weather events are predicted to affect northern Australia, such as tropical cyclones originating in Southeast Asia, and the annual monsoonal winds that blow from Australia's northern neighbors are projected to become more intense (e.g., Jones 2016; Jones and Barbetti 2012). Such alterations in weather conditions would increase the likelihood of winged aphid vectors reaching the continent and bringing damaging PRSV strains with them. The likely effects of climate change in increasing insect vector arrivals from Southeast Asia by increasing cyclones and wind currents emphasizes the need to increase surveillance activities for viral pathogens infecting crops growing in Australia's northern regions. Such surveillance accompanied by rapid action to eliminate or contain any new virus incursions detected would help sustain the current situation regarding the absence of many viral pathogens, or their virulent strains, causing damaging crop diseases elsewhere in the world.

\section{Acknowledgments}

This study forms part of a Ph.D. project by the first author at the University of Western Australia (UWA). The Cooperative Research Centre for Plant Biosecurity (CRCs) (PBCRC61056) and UWA provided a Scholarship for International Research Fees (SIRF). Both organizations and the Commonwealth Scientific and Industrial Research Organisation (CSIRO) provided operating funds. UWA and the Department of Agriculture and Food Western Australia (DAFWA) both provided glasshouse and laboratory facilities for this research. We thank Darren Martin for advice over recombination analysis using the RDP4 package, Ian Small and Monica Kehoe for additional advice, Helen Wilson for some of the virus inoculations and Eva Gajda for testing samples for PRSV by ELISA and both of them for providing glasshouse support at DAFWA, Barry Conde and Denis Persley for suppling the isolates from NT and QLD, and both Robert Creasy and Bill Piasini for glasshouse support at UWA. Martin Barbetti and Mingpei You of the School of Plant Biology, UWA, provided administrative support. The ARC Centre of Excellence in Plant Energy Biology and School of Chemistry and Biochemistry at UWA, and Laura Boykin also provided initial administrative support at the beginning of this project.

\section{Literature Cited}

Altschul, S. F., Gish, W., Miller, W., Myers, E. W., and Lipman, D. J. 1990. Basic local alignment search tool. J. Mol. Biol. 215:403-410.

AVA. 2001. Diagnostic records of the Plant Health Diagnostic Services, Plant Health Centre, Agri-food and Veterinary Authority, Singapore. http://www.ava.gov.sg/ explore-by-sections/plants/plant-health-and-pest-management/plant-health-services

Bailey, P., Chang, D. K., Nones, K., Johns, A. L., Patch, A., Gingras, M., et al 2016. Genomic analyses identify molecular subtypes of pancreatic cancer. Nature 531:47-52.

Bao, Y., Chetvernin, V., and Tatusova, T. 2014. Improvements to pairwise sequence comparison (PASC): a genome-based web tool for virus classification. Arch. Virol. 159:3293-3304.

Bateson, M., and Dale, J. 1992. The nucleotide sequence of the coat protein gene and 3' untranslated region of papaya ringspot virus type W (Aust). Arch. Virol. 123:101-109.

Bateson, M. F., Henderson, J., Chaleeprom, W., Gibbs, A. J., and Dale, J. L. 1994 Papaya ringspot potyvirus: Isolate variability and the origin of PRSV type P (Australia). J. Gen. Virol. 75:3547-3553.

Bateson, M. F., Lines, R. E., Revill, P., Chaleeprom, W., Ha, C. V., Gibbs, A. J., and Dale, J. L. 2002. On the evolution and molecular epidemiology of the potyvirus Papaya ringspot virus. J. Gen. Virol. 83:2575-2585.

Bayot, R. G., Villegas, V. N., Magdalita, P. M., Jovellana, M. D., Espino, T. M., and Exconde, S. B. 1990. Seed transmissibility of papaya ringspot virus. Philipp. J. Crop Sci. 15:107-111.

Boni, M. F., Posada, D., and Feldman, M. W. 2007. An exact nonparametric method for inferring mosaic structure in sequence triplets. Genetics 176:1035-1047.

Büchen-Osmond, C., Crabtree, K., Gibbs, A., and Mclean, G. 1988. Viruses of plants in Australia. Descriptions and lists from the VIDE database. Australian National University, Canberra, Australia.

CABI/EPPO. 2013. Papaya ringspot virus. Distribution Maps of Plant Diseases, No. 902. CAB International, Wallingford, U.K.

Chin, M., Ahmad, M. H., and Tennant, P. 2007. Momordica charantia is a weed host reservoir for Papaya ringspot virus type P in Jamaica. Plant Dis. 91:1518. 
Clark, M. F., and Adams, A. N. 1977. Characteristics of the microplate method of enzyme-linked immunosorbent assay for the detection of plant viruses. J. Gen. Virol. 34:475-483.

Coutts, B. A., and Jones, R. A. C. 2005. Incidence and distribution of viruses infecting cucurbit crops in the Northern Territory and Western Australia. Crop Pasture Sci. 56:847-858.

Coutts, B. A., Kehoe, M. A., and Jones, R. A. C. 2011a. Minimising losses caused by Zucchini yellow mosaic virus in vegetable cucurbit crops in tropical, subtropical and Mediterranean environments through cultural methods and host resistance. Virus Res. 159:141-160.

Coutts, B. A., Kehoe, M. A., Webster, C. G., Wylie, S. J., and Jones, R. A. C. 2011 b. Zucchini yellow mosaic virus: biological properties, detection procedures and comparison of coat protein gene sequences. Arch. Virol. 156:2119-2131.

Davis, R. I., Thomas, J. E., McMichael, L. A., Dietzgen, R. G., Callaghan, B., James, A. P., Gunua, T. G., and Rahamma, S. 2002. Plant virus surveys on the island of New Guinea and adjacent regions of northern Australia. Australas. Plant Pathol. 31:385-390.

Desbiez, C., and Lecoq, H. 2008. Evidence for multiple intraspecific recombinants in natural populations of Watermelon mosaic virus (WMV, potyvirus). Arch. Virol. 153:1749-1754.

Gibbs, A. J., Mackenzie, A. M., Wei, K., and Gibbs, M. J. 2008. The potyviruses of Australia. Arch. Virol. 153:1411-1420.

Gibbs, M. J., Armstrong, J. S., and Gibbs, A. J. 2000. Sister-scanning: A Monte Carlo procedure for assessing signals in recombinant sequences. Bioinformatics 16: 573-582.

Greber, R. S. 1969. Viruses infecting cucurbits in Queensland. Qld. J. Agric. Anim. Sci. 26:145-171.

Guerret, M. G. L., Nyalugwe, E. P., Maina, S., Barbetti, M. J., van Leeur, A. G. J., and Jones, R. A. C. 2017. Biological and molecular properties of a Turnip mosaic virus (TuMV) strain that breaks TuMV resistances in Brassica napus. Plant Dis. 101:674-683.

Herrington, M. E. 1987. Yield and quality of Cucurbita maxima increase with delayed infection by papaya ringspot virus type W. Qld. J. Agric. Anim. Sci. 44:117-121.

Hutterer, K. P. 1983. The natural and cultural history of Southeast Asian agriculture: Ecological and evolutionary considerations. Anthropos 78:169-212.

James, D., Sanderson, D., Varga, A., Sheveleva, A., and Chirkov, S. 2016. Genome sequence analysis of new isolates of the Winona strain of Plum pox virus and the first definitive evidence of intrastrain recombination events. Phytopathology 106: 407-416.

Jones, R. A. C. 1996. Report on survey for virus diseases in crops in the Ord River Irrigation Area. Department of Agriculture Western Australia, Perth, Australia.

Jones, R. A. C. 2009. Plant virus emergence and evolution: Origins, new encounter scenarios, factors driving emergence, effects of changing world conditions, and prospects for control. Virus Res. 141:113-130.

Jones, R. A. C. 2016. Future scenarios for plant virus pathogens as climate change progresses. Adv. Virus Res. 95:87-147.

Jones, R. A. C., and Barbetti, M. J. 2012. Influence of climate change on plant disease infections and epidemics caused by viruses and bacteria CAB Reviews 7, No. 22, 1-32. http://www.cabi.org/cabreviews.

Jones, R. A. C., and Kehoe, M. A. 2016. A proposal to rationalize within-species plant virus nomenclature: Benefits and implications of inaction. Arch. Virol. 161:2051-2057.

Katoh, K., Misawa, K., Kuma, K.-i., and Miyata, T. 2002. MAFFT: a novel method for rapid multiple sequence alignment based on fast Fourier transform. Nucleic Acids Res. 30:3059-3066.

Kearse, M., Moir, R., Wilson, A., Stones-Havas, S., Cheung, M., Sturrock, S., Buxton, S. Cooper, A., Markowitz, S., Duran, C., Thierer, T., Ashton, B., Meintjes, P., and Drummond, A. 2012. Geneious basic: An integrated and extendable desktop software platform for the organization and analysis of sequence data. Bioinformatics 28:1647-1649.

Kehoe, M. A., Coutts, B. A., Buirchell, B. J., and Jones, R. A. C. 2014. Plant virology and next generation sequencing: experiences with a Potyvirus. PLoS One 9:e104580.

Kumar, S., Stecher, G., and Tamura, K. 2016. MEGA7: Molecular evolutionary genetics analysis version 7.0 for bigger datasets. Mol. Biol. Evol. 33:1870-1874.

Levin, J. Z., Yassour, M., Adiconis, X., Nusbaum, C., Thompson, D. A., Friedman, N., Gnirke, A., and Regev, A. 2010. Comprehensive comparative analysis of strand-specific RNA sequencing methods. Nat. Methods 7:709-715.

Liu, L., Li, Y., Li, S., Hu, N., He, Y., Pong, R., and Law, M. 2012. Comparison of next-generation sequencing systems. J. Biomed. Biotechnol. 2012:373945.

Loman, N. J., Misra, R. V., Dallman, T. J., Constantinidou, C., Gharbia, S. E., Wain, J., and Pallen, M. J. 2012. Performance comparison of benchtop highthroughput sequencing platforms. Nat. Biotechnol. 30:434-439.

Magdalita, P. M., Bayot, R. G., and Villegas, V. N. 1990. Diplocyclos palmatus L. Jeffrey: a new weed host of papaya ringspot virus. Philipp. J. Crop Sci. 15:163-168.

Magdalita, P. M., Villegas, V. N., Pimentel, R. B., and Bayot, R. G. 1988. Reaction of papaya (Carica papaya L.) and related Carica species to papaya ringspot virus. Philipp. J. Crop Sci. 13:129-132.

Maina, S., Edwards, O. R., de Almeida, L., Ximenes, A., and Jones, R. A. C. 2016a. Complete genome sequences of the Carlavirus Sweet potato chlorotic fleck virus from East Timor and Australia. Genome Announc. 4:e00414-16.

Maina, S., Edwards, O. R., and Jones, R. A. C. 2016b. First complete genome sequence of Pepper vein yellows virus from Australia. Genome Announc. 4:e0450-16.
Maina, S., Edwards, O. R., de Almeida, L., Ximenes, A., and Jones, R. A. C. 2016c. Complete genome sequences of the Potyvirus Sweet potato virus 2 from East Timor and Australia. Genome Announc. 4:e00504-16.

Maina, S., Edwards, O. R., de Almeida, L., Ximenes, A., and Jones, R. A. C 2016d. First complete genome sequence of Suakwa aphid-borne yellows virus from East Timor. Genome Announc. 4:e00718-16.

Maina, S., Edwards, O. R., Barbetti, M. J., de Almeida, L., Ximenes, A., and Jones, R. A. C. 2016e. Deep sequencing reveals complete genome of Sweet potato virus $G$ from East Timor. Genome Announc. 4:e0957-16.

Maina, S., Edwards, O. R., de Almeida, L., Ximenes, A., and Jones, R. A. C. $2016 f$ First complete genome sequence of Bean common mosaic necrosis virus from East Timor. Genome Announc. 4:e01049-16.

Martin, D. P., Lemey, P., Lott, M., Moulton, V., Posada, D., and Lefeuvre, P. 2010 RDP3: A flexible and fast computer program for analyzing recombination. Bioinformatics 26:2462-2463.

Martin, D. P., Murrell, B., Golden, M., Khoosal, A., and Muhire, B. 2015. RDP4 Detection and analysis of recombination patterns in virus genomes. Virus. Evol. 1:vev003.

Martin, D. P., Williamson, C., and Posada, D. 2005. RDP2: Recombination detection and analysis from sequence alignment. Bioinformatics 21:260-262.

Morlan, J. D., Qu, K., and Sinicropi, D. V. 2012. Selective depletion of rRNA enables whole transcriptome profiling of archival fixed tissue. PLoS One 7:e42882

Nagano, A. J., Honjo, M. N., Mihara, M., Sato, M., and Kudoh, H. 2015. Detection of plant viruses in natural environments by using RNA-Seq. Methods Mol. Biol. 1236:89-98.

Ndunguru, J., Taylor, N. J., Yadav, J., Aly, H., Legg, J. P., Aveling, T., Thompson, G., and Fauquet, C. M. 2005. Application of FTA technology for sampling, recovery and molecular characterization of viral pathogens and virus-derived transgenes from plant tissues. Virol. J. 2:45

Nyalugwe, E. P., Jones, R. A. C., Barbetti, M. J., and Kehoe, M. A. 2015. Biological and molecular variation amongst Australian Turnip mosaic virus isolates. Plant Pathol. 64:1215-1223.

Ohshima, K., Tomitaka, Y., Wood, J. T., Minematsu, Y., Kajiyama, H., Tomimura, K., and Gibbs, A. J. 2007. Patterns of recombination in Turnip mosaic virus genomic sequences indicate hotspots of recombination. J. Gen. Virol. 88:298-315.

Ohshima, K., Yamaguchi, Y., Hirota, R., Hamamoto, T., Tomimura, K., Tan, Z., Sano, T., Azuhata, F., Walsh, J. A., Fletcher, J., Chen, J., Gera, A., and Gibbs, A. 2002 Molecular evolution of Turnip mosaic virus: evidence of host adaptation, genetic recombination and geographical spread. J. Gen. Virol. 83:1511-21.

Olarte-Castillo, O. X. A., Fermin, G., Tabima, J., Rojas, Y., Tennant, P. F., Fuchs, M., Sierra, R., Bernal, A. J., and Restrepo, S. 2011. Phylogeography and molecular epidemiology of Papaya ringspot virus. Virus Res. 159:132-140.

Opina, O. S. 1986. Studies on a new virus disease of papaya in the Philippines. Pages 157-168 in: Proceedings of conference on plant virus diseases of horticultural crops in the tropics and subtropics, Food and Fertilizer Technology Centre for the Asian and Pacific Region, Taipei, Taiwan.

Padidam, M., Sawyer, S., and Fauquet, C. M. 1999. Possible emergence of new geminiviruses by frequent recombination. Virol. 265:218-25.

Pirone, T. P., and Harris, K. F. 1977. Nonpersistent transmission of plant viruses by aphids. Annu. Rev. Phytopathol. 15:55-73.

Posada, D., and Crandall, K. A. 2001. Evaluation of methods for detecting recombination from DNA sequences: Computer simulations. Proc. Natl. Acad. Sci. USA 98:13757-13762.

Purcifull, D. E., and Hiebert, E. 1979. Serological distinction of Watermelon mosaic virus isolates. Phytopathology 69:112-116.

Rai, I. G., Temaja, M., Sudiarta, I. P., and Darmiati, N. N. 2015. Papaya ringspot virus (PRSV) causing ringspot disease on papaya in Bali. J. Biol. Agric. Health 5:50-55.

Reuter, J. A., Spacek, D. V., and Snyder, M. P. 2015. High-throughput sequencing technologies. Mol. Cell 58:586-597.

Sigurgeirsson, B., Emanuelsson, O., and Lundeberg, J. 2014. Analysis of stranded information using an automated procedure for strand specific RNA sequencing. BMC Genomics 15:631.

Smith, J. M. 1992. Analyzing the mosaic structure of genes. J. Mol. Evol. 34:126-129.

Somowiyarjo, S. 1993. Detection and identification of cucurbit viruses in Yogyakarta. Ilmu Pertanian 5:657-664.

Stranneheim, H., Werne, B., Sherwood, E., and Lundeberg, J. 2011. Scalable transcriptome preparation for massive parallel sequencing. PLoS One 6:e21910

Tan, Z., Wada, Y., Chen, J., and Ohshima, K. 2004. Inter- and intra-lineage recombinants are common in natural populations of Turnip mosaic virus. J. Gen. Virol. 85:2683-2696.

Thomas, J. E., and Dodman, R. L. 1993. The first record of papaya ringspot virustype P from Australia. Australas. Plant Pathol. 22:2-7.

Wahab, N. 1991. Papaya ringspot virus disease (PRVS) is here in Malaysia. MAPPS Newsl. 15:36.

Webster, C. G. 2008. Characterisation of Hardenbergia mosaic virus and development of microarrays for detecting viruses in plants. $\mathrm{PhD}$ thesis, Murdoch University, Perth, Australia.

Yeh, S. D., and Gonsalves, D. 1984. Evaluation of induced mutants of papaya ringspot virus for control by cross protection. Phytopathology 74:1086-1091.

Zitter, T. A., Hopkins, D. L., Claude, E., and Thomas, C. E., eds. 1996. Compendium of Cucurbit diseases. American Phytopathological Society, St. Paul, MN. 